\title{
Tinjauan Hukum Islam Terhadap Sistem Upah jasa Pemelihara Hewan Ternak sapi Dengan Gabah Hasil Panen (Studi Kasus Desa Beroangin Kecamatan Mapilli)
}

\author{
Rahim, Busrah \\ Prodi Hukum Ekonomi Syariah, Fakultas Agama Islam, Universitas Al Asyariah \\ Mandar \\ Rabd7129@gmail.com
}

\begin{abstract}
Abstrak
penelitian ini berupa penelitian lapangan yang bertujuan untuk mengetahui bagaimana sistem upah jasa pemelihara hewan ternak (sapi) dengan gabah hasil panen di Desa Beroangin Kecamatan Mapilli dan bagaimana tinjauan hukum Islam terhadap sistem upah dalam transaksi ini. Lokasi Penelitian berada di Desa Beroangin Kecamatan Mapilli. Hasil penelitian menunjukkan bahwa sistem upah jasa pemelihara hewan ternak (sapi) dengan gabah hasil panen hanya dilakukan oleh peternak yang propesinya sebagai petani penghasil gabah dan buruh yang punya lahan dan pakan yang mendukun untuk hewan ternak (sapi). Perhitungan upah buruh pemelihara hewan ternak (sapi) dilihat dari banyaknya sapi yang dipelihara kemudian ditentukan 1 sapi sama dengan 1 karung gabah seberat $100 \mathrm{~kg}$. Apabila terjadi kegagalan panen maka upah akan diganti oleh pemberi kerja dengan upah jenis yang sama atau dengan uang seharga gabah yang harus diberikan. Tinjauan hukum Islam terhadap sistem upah dalam transaksi ini, ditinjau dari komoditas yang dijadikan sebagai upah untuk buruh yang sifatnya tidak jelas (Gharar) diperjelas oleh ganti yang sudah disepakati diawal akad. Transaksi ini tidak bertentangan dengan syara' dan hukumnya boleh dilakukan karena berlangsung atas dasar suka sama suka diantara kedua belah pihak.selain itu sistem seperti ini sudah menjadi kebiasaan yang berlaku di masyarakat dan kebiasaan itu bisa menjadi acuan hukum dalam Islam selama tidak merugikan serta tidak ada nash yang melarang.
\end{abstract}

Kata Kunci : Hukum Islam, Sistem upah, jasa.

\begin{abstract}
This research is a field research that aims to find out how the wage system for keeping livestock (cow) with grain yields is in the Beroangin Village, Mapilli District and how Islamic law reviews the wage system in this transaction. The research location is in Beroangin Village, Mapilli District. The results showed that the wage system for keeping livestock (cows) with grain yields was only carried out by breeders whose professions were grain-producing farmers and laborers who owned land and feed that supported livestock (cows). Calculation of wages for livestock keeping workers (cows) is seen from the number of cows raised and then determined that 1 cow is equal to 1 sack of grain weighing $100 \mathrm{~kg}$. In the event of crop failure, the employer will replace the wages with the same type of wages or with money for the price of grain that must be given. The review of Islamic law on the wage system in this transaction, in terms of commodities that are used as wages for workers
\end{abstract}


whose nature is not clear (Gharar) is clarified by the compensation agreed at the beginning of the contract. This transaction does not conflict with syara' and the law is permissible because it takes place on a consensual basis between the two parties. Apart from that, such a system has become a prevailing custom in society and this custom can be used as a legal reference in Islam as long as it is not harmful and does not exist. text that forbids.

Keywords: Islamic Law, Wage system, service.

\section{PENDAHULUAN}

Islam menganjurkaan manusia untuk senantiasa bekerja dan berusaha untuk mencari mata pencaharian yang dapat memenuhi kebutuhan masyarakat dan dapat mengatasi segala urusannya. Islam juga mengajarkan dasar dasar pokok yang diambil dari Al-Qur'an dan hadist sebagai landasan hukum perbuatan manusia yang taat kepadanya tentang tata cara mencari mata pencaharian karena tidak semua cara itu dibenarkan oleh syariat Islam.

Dalam mencari mata pencaharian manusia selalu membutuhkan bantuan Manusia lainnya untuk memenuhi kebutuhannya yang diistilahkan dengan kegiatan Mu'amalah. Kegiatan mu'amalah merupakan kegiatan yang menyangkut hubungan antar manusia. Transaksi mu'amalah banyak macamnya salah satunya yaitu upahmengupah. Sistem upah-mengupah telah diatur di dalam Al-Qur'an dan diperluas penjelasannya di dalam hadist. Dengan adanya dalil-dalil tersebut, maka sudah sepatutnya manusia memenuhi aturan-aturan yang telah ditetapkan di dalamnya. Upah-mengupah telah ditentukan aturan-aturan hukumnya seperti rukun, syarat maupun bentuk sewa yang diperbolehkan. Dalam praktiknya harus dikerjakan secara konsekuen dan memberikan manfaat bagi yang bersangkutan. ${ }^{1}$

Upah mengupah dalam bahasa Arab disebut Al-Ijarah. Ijarah identik dengan akad jual beli, namun dalam ijarah kepemilikan barang dibatasi dengan waktu. ${ }^{2}$ Dalam konsep ijarah, pemilik yang menyewakan manfaat disebut mu'jir (orang yang menyewakan) sedangkan pihak lainnya yang memberikan sewa disebut musta’jir (orang yang menyewa atau penyewa), dan sesuatu yang diakad untuk diambil manfaatnya disebut ma’jur (sewaan) serta jasa yang diberikan sebagai imbalan manfaat disebut ajran atau ujrah (upah). Jasa atau pelayanan diperlukan karena manusia membutuhkan tenaga atau keahlian orang lain untuk memenuhi kebutuhannya.

${ }^{1}$ Chairuman Pasaribu dan Suhrawardi K. Lubis, Hukum Perjanjian Dalam Islam (Jakarta: Sinar Grafika, 1996), h. 53

${ }^{2}$ Dimyauddin Djuwaini, Pengantar Fiqh Muamalah, (Cet.1: Yokyakarta: Pustaka Belajar, 2008), h. 153 
Menjual jasa atau layanan kepada orang lain diperbolehkan dalam ajaran Islam. Sama halnya dengan penjualan barang dan komoditas, penjualan jasa diperbolehkan untuk memenuhi kebutuhan dalam kehidupannya. Sebagai mahluk sosial (zoon politicon) dan mahluk ekonomi (homo economicus), manusia senantiasa membutuhkan jasa orang lain. Tidak seorang pun manusia di dunia ini yang mampu memenuhi kebutuhannya sendirian tanpa bantuan jasa orang lain, terlebih dizaman modern saat ini ketika kebutuhan manusia semakin konfleks, maka kebutuhan akan jasa orang lain semakin banyak pula ${ }^{3}$.Adapun orang yang mempunyai tenaga dan keahlian membutuhkan uang sebagai bayaran jasa yang dilakukannya.

Terjadinya perbedaan antara orang kaya dan orang miskin dalam hal harta yang mereka miliki beserta segala fasilitasnya termasuk juga derajat mereka yang berbeda, semua itu merupakan ketentuan (takdir) Allah, agar supaya mereka saling membutuhkan satu dengan yang lain. Disinilah berlaku penjualan jasa kepada orang yang membutuhkannya, karena seseorang tidak akan bisa melakukan segala sesuatunya tanpa jasa atau layanan orang lain.

Transaksi upah secara umum dalam Islam telah banyak yang melakukanya. Masyarakat Islam di Indonesia salah satunya, bahkan yang beragama diluar Islam, juga mengalami atau mengenal istilah "upah". Hal ini dapat dibuktikan dengan banyaknya pekerja, baik itu karyawan perusahaan, pegawai negara, petani, peternak, nelayan, dan sebagainya yang berada di Indonesia. Di wilayah bagian timur Indonesia secara umum juga termasuk dalam bagian kategori tersebut, secara mengkhusus dibagian Sulawesi Barat. ${ }^{4}$

Proses Upah mengupah terjadi karena adanya hubungan timbal balik antara yang terlibat dalam transaksi sebagai bentuk penghargaan dan ucapan terima kasih karena telah menolongnya, baik dalam bentuk pekerjaan fisik ataupun non fisik. Di dunia peternakan misalnya, secara umum pada masyarakat di wilayah Sulawesi Barat, Kabupaten Polewali Mandar khususnya. Dikenal salah satu bidang pekerjaan yang berbentuk jasa, pekerjaan itu disebut buruh pemelihara hewan ternak (sapi). Buruh pemelihara hewan ternak (sapi) adalah salah satu bidang pekerjaan yang tidak asing lagi di Kabupaten ini, apalagi terkhusus diwilayah Desa Beroangin Kecamatan Mapilli, pekerjaan ini telah ada dari dulu sampai sekarang, dan pekerjaan ini termasuk dalam kategori buruh. Namun yang menjadi persoalan dalam pekerjaan ini

${ }^{3}$ Prof. Dr. H. Idri, M .Ag., Hadis Ekonomi (Ekonomi dalam perspektif Hadis Nabi), Ed. I ( Cet Ke 1: Jakarta: PrenadaMedia Group, 2015). h. 232

${ }^{4}$ Andi Sudarmin Azis, J-Alif Jurnal Penelitian Hukum Ekonomi Syariah, Tinjauan Hukum Islam Terhadap Buruh Pattei Anjoro (Studi Kasus Desa Leko Pa'dis Kecamatan Tinambung Kabupaten Polewali Mandar, (Lembaga Penelitian dan Pengabdian Masyarakat Universitas Al Asyariah Mandar, 2017) 
adalah upah buruh. Pemberi kerja dalam hal ini pemilik sapi (yang membutuhkan jasa) menjanjikan upah berupa gabah hasil panen sebagai imbalan dari pekerjaan tersebut, yang umumnya kita ketahui bahwa gabah hasil panen merupakan komoditas yang belum pasti hasilnya dalam artian hasil panen gabah bisa saja gagal, dan sesuatu yang tidak pasti itu adalah gharar.

\section{METODE PENELITIAN}

Jenis penelitian ini menggunakan jenis penelitian kualitatif lapangan, yang mengandung makna bahwa temuan tidak diperoleh melalui data statistik atau jenis perhitungan lainnya, penelitian ini menghasilkan kata-kata tertulis atau lisan dari perilaku manusia yang diamati, penelitian ini termasuk penelitian lapangan, yaitu mengumpulkan data. dimana fenomena itu terjadi diteliti. Lokasi penelitian berada di Desa Beroangin, Kecamatan Mapilli. Sumber informasi penelitian ini adalah sumber data primer dan sekunder. Metode pengumpulan data mengakomodasi observasi, wawancara dan dokumentasi. Teknik pengumpulan dan analisis data diterapkan dalam 3 (tiga) cara, yaitu metode induktif, deduktif dan komparatif. Pengujian keabsahan informasi dalam jenis kredibilitas dengan teknik pemeriksaan dalam jenis triangulasi

\section{HASIL PENELITIAN}

\section{A. Sistem upah jasa pemelihara hewan ternak (sapi) dengan gabah hasil panen di Desa Beroangin}

Upah merupakan salah satu penerimaan imbalan dari pemberi kerja kepada penerima pekerjaan termasuk tunjangan, baik bagi pekerja itu sendiri maupun keluarganya. Biasanya upah diberikan kepada pekerja yang melakukan pekerjaan berat dan lebih banyak menggunakan tenaga/kekuatan fisik. Pembayaran jumlah upah biasanya ditentukan hari ke hari atau berdasar pada jenis pekerjaan yang diselesaikan. $^{5}$

Pada transaksi Upah pemelihara hewan ternak (sapi) dengan gabah hasil panen yang dilakukan oleh sebagian masyarakat Desa Beroangin penulis mencoba mendeskripsikan bagaimana sistem tersebut dilakukan dan apa-apa saja yang menjadi masalah dalam transaksi ini, serta bagaimana manfaat dan keuntungannya, dengan demikian penulis turun langsung kelapangan agar mendapatkan bukti yang kongkrit mengenai bagaimana sebenarnya sistem upah pemelihara hewan ternak (sapi) dengan gabah hasil panen diterapkan oleh masyarakat Desa Beroangin.

${ }^{5}$ F. Winarni dan G. Sugiarso, n Administrasi Gaji Dan Upah, (Yolyakarta: Pusta Widyamata, 2006), h. 16 
Namun berdasarkan penelusuran yang dilakukan oleh penulis terkait bagaimana sistem ini dilakukan sebagaimana yang berlaku di Desa tersebut, penulis tidak menemukan adanya ketimpangan-ketimpangan atau hal-hal yang membuat salah satu dari kedua belah pihak dirugikan dalam transaksi tersebut.

Adapun hasil wawancara dari beberapa masyarakat Desa Beroangin terkait dengan sistem upah pemelihara hewan ternak (sapi) dengan gabah hasil panen akan diklasifikasikan dalam beberapa bagian yaitu :

1. Pemelihara (buruh) dan pemilik sapi (pemberi kerja)

Berangkat dari wawancara Kamaruddin selaku tokoh masyarakat di Desa Beroangin menyatakan :

"Transaksi Upah-mengupah yang dilakukan antara pemelihara sapi dan pemilik sapi dengan perjanjian upah gabah hasil panen, yang dilakukan oleh masyarakat desa Beroangin atau yang diistilahkan dengan ma'ammbi, saping pare adalah salah satu transaksi dalam bentuk kerja sama yang dilakukan oleh sebagian masyarakat setempat sebagai mata pencaharian yang sudah lama dilakukan, dimana pemilik sapi sebagai pemberi kerja menyerahkan sapi-sapi mereka kepada salah satu pemelihara sapi (buruh) untuk dipelihara dengan kesepakatan upah gabah hasil panen. Dalam transaksi seperti ini peternak (pemilik sapi) yang terlibat adalah mereka yang tidak hanya bekerja sebagai peternak namun bekerja juga sebagai petani padi penghasil gabah, para peternak ini (pemilik sapi) biasanya akan mempekerjakan sapi-sapi mereka kepada pemelihara sapi (buruh) apabila mereka turun sawah atau biasa diistilahkan dengan merrawung galung hal ini disebabkan karna ketika para petani turun sawah (mulai menabur benih gabah) maka lahan dan pakan untuk ternak yang ada disawah akan hilang dan secara otomatis para petani yang memiliki hewan ternak sapi akan sangat kesusahan untuk memberikan pakan pada ternak-ternak mereka kemudian selanjutnya pemelihara yang dipercayakan untuk memelihara sapi-sapi mereka adalah masyarakat yang tinggal disekitar lahan serta pakan yang mendukung biasanya pemelihara ini adalah mereka yang punya lahan luas serta pakan yang banyak untuk ternak sapi dan tentunya butuh gabah.”. ${ }^{6}$

"Kebanyakan dari kami para peternak yang butuh buruh dan menyewa dengan upah gabah adalah para petani penghasil gabah, karna pada saat turun sawah kami kewalahan dalam memelihara sapi-sapi kami akibat sibuknya kami disawah serta hilangnya makanan sapi disawah, dan orang yang kami percayakan untuk memelihara sapi-sapi kami disaat seperti ini adalah orang yang mampu, dalam artian orang punya pakan untuk ternak sapi.,"7

\footnotetext{
${ }^{6}$ Kamaruddin, Tokoh Masyarakat Desa Beroangin, Kec. Mapilli Kab. Polman, Sulbar, Wawancara oleh penulis di Beroangin, 18 April 2021

${ }^{7}$ Rahaman, pemilik sapi (pemberi kerja) Desa Bondra, Kec. Mapilli Kab. Polman, Sulbar, Wawancara oleh penulis di Bondra, 18 april 2021
} 
Berdasarkan uraian di atas maka dapat dipahami bahwa transaksi upah pemelihara Hewan ternak (sapi) dengan gabah hasil panen atau ma'ammbi, saping pare dalam bahasa sehari-hari masyarakat Desa Beroangin (bahasa Mandar) itu adalah salah satu bentuk kerja sama diantara dua pihak yang sudah lama dilakukan sebagai mata pencaharian masyarakat setempat dimana para pelaku (pemberi kerja) yang terlibat menyewa buruh dengan upah gabah hasil panen dalam transaksi ini tidak hanya bekerja sebagai peternak tapi juga petani penghasil gabah yang membutuhkan buruh untuk memelihara sapi-sapi mereka, kemudian pihak buruh (pemelihara) adalah mereka yang butuh gabah dan kebetulan punya pakan ternak sapi yang banyak serta lahan yang luas. Para peternak dalam transaksi ini biasanya akan memasukkan sapi-sapi mereka untuk dipelihara oleh buruh pada saat mereka mulai turun sawah atau merrawung galung dalam bahasa sehari-hari masyarakat Desa Beroangin (bahasa Mandar), hal ini disebabkan karna pada saat mereka mulai turun sawah maka lahan dan pakan untuk ternak sapi yang ada disawah akan hilang dan secara otomatis para peternak akan kesusahan dalam memberikan pakan pada sapi-sapi mereka, ditambah lagi tidak adanya waktu mereka dalam memelihara sapi akibat sibuknya mereka disawah.

\section{Perhitungan upah pada setiap sapi yang di pelihara oleh Buruh}

Dalam hal ini sebagaimana yang diungkapkan oleh salah satu pemelihara sapi (buruh) dan pemilik sapi dalam transaksi tersebut menuturkan bahwa :

"Sebagaimana kebiasaan kami penentuan upah yang sudah disepakati dengan pemilik sapi hitungannya satu sapi sama dengan satu karung gabah apabila sapi tersebut punya anak maka upahnya disesuaikan dengan besar anak sapi tersebut." 8

"Seratus kilogram Gabah sama dengan satu ekor sapi, jadi apabila sapi tersebut punya anak namun belum bisa diikat (masih sangat kecil) maka tidak dikenakan sewa tapi bilamana anak tersebut sudah bisa diikat maka akan dikenakan sewa""

Dari hasil wawancara penulis dengan pemelihara hewan ternak sapi (buruh) dan pemilik sapi (pemberi kerja) dapat diketahui bahwa penentuan upah berdasarkan kebiasaan dapat dilihat dari berapa banyak sapi yang dipelihara oleh buruh lalu kemudian ditentukan satu sapi sama dengan satu karung gabah dengan berat $100 \mathrm{~kg}$, apabila sapi tersebut memiliki anak maka

\footnotetext{
${ }^{8}$ Pak Sahril, pemelihara sapi (buruh) Desa beroangin, Kec. Mapilli Kab. Polman,
} Sulbar, Wawancara oleh penulis di Beroangin, 18 april 2021

${ }^{9}$ Rahaman, pemilik sapi (pemberi kerja) Desa Bondra, Kec. Mapilli Kab. Polman, Sulbar, Wawancara oleh penulis di Bondra, 18 april 2021 
bayaran upah yang akan dikenakan pada anak sapi tersebut disesuaikan dengan besarnya anak sapi berdasarkan kesepakatan diantara dua pihak yang bertransaksi, Untuk lebih jelasnya akan diuraikan pada tabel berikut :

Tabel 3.1

Perhitungan upah buruh

\begin{tabular}{|c|l|c|c|}
\hline No & Sapi yang dipelihara buruh & Upah gabah & Berat (kg) \\
\hline 1. & 1 ekor induk sapi & 1 karung Gabah & $100 \mathrm{~kg}$ \\
\hline 2. & 1 ekor sapi dewasa & 1 karung gabah & $100 \mathrm{~kg}$ \\
\hline 3. & $\begin{array}{l}1 \text { ekor anak sapi yang sudah } \\
\text { bisa di ikat }\end{array}$ & $\begin{array}{c}1 / 2 \text { karung } \\
\text { Gabah }\end{array}$ & $50 \mathrm{~kg}$ \\
\hline 4. & $\begin{array}{l}\text { 1 ekor anak sapi yang belum } \\
\text { bisa diikat }\end{array}$ & - & - \\
\hline
\end{tabular}

3. Lama pemelihara (buruh) memelihara sapi

Sebagaimana yang telah dikemukakan oleh Hasrul Buruh pemelihara hewan ternak (sapi) dan Abdul Majid tokoh Agama yang juga bekerja sebagai Buruh pemelihara hewan ternak (sapi) mengatakan bahwa :

Lamanya tergantung lama tumbuhnya tanaman padi hingga panen, karna mereka memasukkan sapi-sapi mereka pada saat mereka mulai menabur benih disawah. ${ }^{10}$

Lama kami memelihara sapi hingga mendapatkan upah biasanya 3 bulan lebih, namun biasa juga 4 bulan lebih, karena para pemilik sapi terkadang terlambat memasukkan sapi-sapi mereka kadang juga sangat cepat. ${ }^{11}$

Berdasarkan penjelasan di atas maka dapat dipahami bahwa waktu buruh memelihara sapi-sapi para peternak hingga mendapatkan upah itu dihitung dari berapa lama tanaman padi ditanam hingga panen atau sama dengan 3 bulan lebih sampai 4 bulan, hal ini dikarenakan pada saat petani turun sawah (mulai menabur benih) maka pakan untuk ternak disawah akan

${ }^{10}$ Hasrul, pemelihara sapi (buruh) Desa beroangin, Kec. Mapilli Kab. Polman,

Sulbar, Wawancara oleh penulis di Beroangin, 18 april 2021

${ }^{11}$ Abdul Majid, pemelihara sapi (buruh) Desa beroangin, Kec. Mapilli Kab.

Polman, Sulbar, Wawancara oleh penulis di Beroangin, 18 april 2021 
hilang sehingga pemilik sapi akan memasukkan sapi-sapi mereka untuk dipelihara.

Perhitungan 4 bulan di atas dapat diketahui dengan melihat realita yang terjadi pada proses petani menanam padi, mulai dari pembajakan sawah selama kurang lebih 10 hari kemudian menabur benih dan menunggu hingga benih tumbuh selama kurang lebih 20 hari, selanjutnya benih yang tumbuh akan dipindahkan untuk ditanam kembali, dan lama proses tumbuh tanaman padi hingga panen adalah 90 hari ( 3 bulan). jadi lama proses tumbuh tanaman padi mulai dari pembajakan hingga panen adalah 120 hari (4 bulan). Adapun perhitungan 3 bulan dapat diketahui karna beberapa sebab yaitu :

a. lambatnya para pemilik sapi menyerahkan sapi-sapi mereka kepada buruh untuk dipelihara hal ini disebabkan karna para petani terkadang tidak serentak turun sawah untuk melakukan pembajakan sawah sehingga lahan dan pakan untuk ternak sapi masih ada yang tersisa akibat irigasi yang kurang mendukung, sementara itu mereka para petani yang juga berpropesi sebagai peternak khususnya para pemberi kerja buruh pemelihara hewan ternak sapi, sudah mulai melakukan pembajakan sawah bahkan ada yang sudah menabur benih padi sebagaimana ungkapan salah satu pemilik sapi yang menyatakan bahwa :

“biasai iyapa nadibawai tama saping mua' purami tau mambubur karna malonggang duai enggeang saping,, ${ }^{2}$ Artinya :

"Terkadang kami membawa sapi-sapi kami masuk (untuk dipelihara) ketika kami sudah menabur benih (padi)."

b. Pengembalian sapi kepada pemilik sapi sebelum panen padi, hal ini disebabkan karena panen padi para petani juga kadang tidak serentak dalam artian para petani ada yang lebih awal panen, biasanya mereka yang panen lebih awal adalah para petani yang lebih awal menanam padi. Sebagaimana yang kita ketahui bersama bahwa salah satu faktor pendukung atau kekuatan bagi para peternak untuk pakan sapi-sapi mereka selain rumput segar adalah lahan sawah tempat tumbuh tanaman padi dimana sisa hasil panen padi seperti batang dan daunnya adalah makanan pokok bagi ternak sapi, jadi apabila panen sudah tiba maka sapi akan kembali dilepas untuk digembalakan di sawah, sehingga hal inilah yang membuat para pemilik sapi meminta kepada buruh untuk segera

${ }^{12}$ Kudin, pemilik sapi (pemberi kerja) Desa Bondra, Kec. Mapilli Kab. Polman, Sulbar, Wawancara oleh penulis di Beroangin, 22 april 2021 
mengembalikan sapi-sapi mereka sebagaimana ungkapan Bapak Bahari yang juga seorang petani padi penghasil gabah berpropesi sebagai peternak sapi mengatakan :

“Mua' panenmi dini se'iya namalami lao dipa'annai saping momo ndappa ita' panen, disio tomi dilalang pappiara mappipimbali saping.,,${ }^{13}$ Artinya :

Apabila para petani yang lain sudah panen dan lahan untuk sapi sudah ada, meskipun kami (pemilik sapi) belum panen padi, kami akan tetap meminta kepada buruh untuk segera mengembalikan sapi-sapi kami.

4. pemberian upah kepada pemelihara sapi (buruh)

Pemberian upah adalah salah satu kewajiban bagi pemberi kerja yang harus ditunaikan pada saat pekerjaan yang dilakukan oleh pekerja (buruh) sudah selesai, dimana pemberi kerja dalam hal ini pemilik sapi akan memberikan sesuatu kepada pekerja (buruh pemelihara hewan ternak sapi) berupa gabah sebanyak yang sudah disepakati diawal akad sebagai imbalan dan ucapan terimah kasih atas jerih payah dalam mengembala dan merawat sapi selama beberapa bulan.

Adapun hasil wawancara oleh penulis dengan salah satu buruh pemelihara hewan ternak sapi terkait masalah pengupahan menyatakan bahwa :

'Mua' dibawami sau saping, dite'e, marondong nabawa tomi tia mai tambota, tapi biasa toandi seminggupa mai pura dibawa sau saping mane nabawa tomi tia mai tambota karna mиa' diangmo mala naengei l;e'sau saping, biasai ndappa paneng nanapisoani sau dibawa saping". ${ }^{14}$

Artinya :

Apabila sekarang sapi diantar kepemiliknya, maka besoknya mereka (pemilik sapi) akan mengantar upah kepada kami, tapi terkadang juga satu minggu setelah pengantaran sapi baru upah akan diantar kepada kami hal ini dikarenakan apabila lahan sawah sudah bisa ditempati hewan ternak biasanya mereka (pemilik sapi) yang belum panen gabah, meminta agar sapi diantar.

Dari kutipan wawancara yang telah dituturkan oleh Nadir dapat dipahami bahwa penyerahan upah oleh pemilik sapi (pemberi kerja) berlangsung satu hari setelah pengantaran sapi oleh buruh kepada pemiliknya namun terkadang juga penyerahan upah dilakukan satu minggu setelah pengantaran sapi hal ini disebabkan

${ }^{13}$ Bahari, pemilik sapi (pemberi kerja) Desa Bondra, Kec. Mapilli Kab. Polman, Sulbar, Wawancara oleh penulis di Beroangin, 22 april 2021

${ }^{14}$ Nadir, pemelihara sapi (buruh) Desa beroangin, Kec. Mapilli Kab. Polman, Sulbar, Wawancara oleh penulis di Beroangin, 23 april 2021 
karena pengembalian sapi oleh buruh dilakukan pada saat sebelum pemilik sapi panen padi, dan secara otomatis waktu para buruh memelihara sapi akan terhitung singkat. meskipun demikian waktu para buruh dalam memelihara sapi singkat, namun upah tetap pada jumlah yang sudah disepakati dalam artian upah tidak berkurang.

Dalam hal pengupahan pada transaksi pemelihara Sapi (buruh) dengan pemilik sapi (pemberi kerja) menjadi kekhawatiran penulis diawal, apabila sewaktuwaktu pemilik sapi yang juga berpropesi sebagai petani penghasil gabah mengalami kegagalan panen yang dapat mengakibatkan para buruh pemelihara hewan ternak sapi terancam tidak mendapatkan upah berupa gabah seperti yang diharapkan sebelumnya, dalam hal ini berdasarkan penelusuran di lapangan, penulis menemukan tiga alternatif yang sudah disepakati diawal akad apabila hal tersebut terjadi yaitu Upah akan diganti dengan uang, upah akan diganti dengan beras dengan takaran $50 \mathrm{~kg}$ beras persapi atau upah akan diganti dengan gabah dengan cara pemilik sapi (pemberi kerja) akan membeli gabah atau beras untuk buruh sebanyak yang harus diberikan berdasarkan permintaan pemelihara (buruh) sebagaimana pernyataan salah satu pemilik sapi (pemberi kerja) dan pemelihara sapi (buruh) menyatakan bahwa :

"ketika kami gagal panen maka kami akan menyesuaikan apa yang diinginkan oleh para pemelihara sapi, karna terkadang mereka juga mau mengambil upah berupa uang dan terkadang berupa Gabah, jadi kalau kami tidak punya gabah untuk diberikan maka kami akan beli gabah sebanyak upah yang harus diberikan. ${ }^{15}$

"Dikesepakatan awal memang mereka (pemilik sapi) sudah memberikan pilihan kepada kami ketika terjadi kegagalan panen, tergantung kita maunya apa, kalau kita mau uang maka mereka akan memberikan upah berupa uang sebanyak harga gabah perkarungnya, namun kalau kita tetap ingin gabah maka mereka akan beli gabah untuk kami biasa juga dengan beras seberat $50 \mathrm{~kg} 1$ sapi."

Pernyataan diatas cukup membuktikan bahwa dua pihak yang bertransaksi sudah punya beberapa cara tersendiri untuk mengantisipasi kegagalan panen yang kemunkinan dialami oleh para pemilik sapi (pemberi kerja), hal ini tentunya sudah memadamkan rasa takut yang dirasakan oleh

\footnotetext{
${ }^{15}$ Tahir, pemilik sapi (pemberi kerja) Desa Bondra, Kec. Mapilli Kab. Polman,
}

Sulbar, Wawancara oleh penulis di Beroangin, 20 april 2021

${ }^{16}$ Rasi, pemelihara sapi (buruh) Desa beroangin, Kec. Mapilli Kab. Polman, Sulbar, Wawancara oleh penulis di Beroangin, 18 april 2021 
para buruh yang tadinya terancam tidak mendapatkan upah atau dengan kata lain akan dirugikan dengan pekerjaan ini.

Lebih jauh dijelaskan oleh bapak Mashuda seorang buruh yang bekerja memelihara Hewan ternak (sapi) dengan upah gabah hasil panen menyatakan bahwa :

'Mua' masalah gagal panenna immai se'iya le'saue ndattoi tau rua massussai, karna mengerti tau. sawa' iya ri'o mua' karae' parena, tania anu nabutu-butunni, melo tori tia macoa, tapi namuapami macoa karae 'na pare tania ita mappoelo, elo'na nasang puang'. jadi mua' bassa indi' ke'adaan eee ita' mengerti biasa sa,apa sa,apa mibengang iyamo diala.

Artinya :

Kalau masalah gagal panen mereka disana, kita tidak pernah menyulitkan, karna kami juga mengerti. sebab kalau mereka gagal panen itu bukan kesengajaan mereka, mereka juga ingin berhasil namun apalah daya gagal berhasilnya padi bukan kita yang tentukan semua adalah ketentuan Allah SWT. Jadi apabila hal ini terjadi biasanya kami yang mengerti berapapun yang mereka berikan itulah yang kami terima.

Dari kutipan wawancara yang telah dituturkan oleh bapak Mashuda maka dapat dipahami bahwa masyarakat yang terlibat dalam pekerjaan ini sebagai buruh tidak pernah menyulitkan para pemilik sapi apabila terjadi kegalan panen, hal ini dikarenakan mereka memahami bahwa, kegagalan panen padi terjadi bukan disebabkan karena unsur kesengajaan yang dilakukan oleh para pemilik sapi tentunya mereka para petani (pemilik sapi) juga sangat menginginkan hasil yang baik namun akan tetapi berhasil atau gagalnya mereka adalah ketentuan Allah SWT yang tidak bisa dirubah, begitu juga halnya dengan Hewan ternak sapi yang tidak bisa dijamin keselamatannya atau nyawanya pada saat digembalakan oleh pemelihara (buruh) selama kurang lebih 4 bulan, dalam hal ini para pemilik sapi juga memahami mereka selama bukan akibat kelalaian yang dilakukan oleh pemelihara (buruh), hal ini diungkapkan oleh Tahir salah satu pemilik sapi berpropesi sebagai petani penghasil gabah yang juga bermitra dengan para pemelihara sapi dengan upah gabah hasil panen menyatakan bahwa

${ }^{17}$ Mashuda, pemelihara sapi (buruh) Desa beroangin, Kec. Mapilli Kab. Polman, Sulbar, Wawancara oleh penulis di Beroangin, 18 april 2021 
("Bilamana sapi yang dipelihara mati maka tidak ada tanggung jawab bagi pemelihara selama tidak ada unsur kelalaian atau kesengajaan").

Atas dasar inilah yang membuat mereka saling memahami dan tidak pernah menyulitkan apabila hal-hal yang tidak diinginkan terjadi. Beberapa pernyataan diatas dibuktikan oleh pernyataan Kamaruddin lebih lanjut, sebagai masyarakat yang hidup dilingkungan para pelaku transaksi pemelihara hewan ternak (sapi) dengan upah gabah hasil panen, beliau menyatakan bahwa :

"Saya sebagai masyarakat melihat masyarakat yang lain melakukan pekerjaan ini tidak pernah ada perselisihan mengenai masalah upah. Terkait masalah ketakutan pemelihara akan terjadinya kegagalan panen padi pada pemilik sapi itu sudah difikirkan oleh kedua belah pihak dan sudah memiliki alternatif yang tidak sama sekali memberatkan bagi mereka. Kenapa demikian ? karna mereka sudah saling memahami, pemelihara sapi memahami pemilik sapi ketika terjadi kegagalan dan begitupun pemilik sapi memahami bagaimana kesulitan pengembala sapi selama kurang lebih 4 bulan lamanya dalam mengembala, tidak pernah kami mendapati mereka memperhitungkan ketika misalnya sapi-sapi yang digembala kurus maka takaran upah juga dikurangi.,"

Pernyataan di atas menunjukkkan bahwa sebelum masyarakat terlibat dalam transaksi ini lebih jauh mereka sudah memikirkan akan kegagalan tersebut olehnya itu untuk menghindari perselisihan yang kemunkinan terjadi, terlebih dahulu mereka mencari solusi yang tepat untuk disepakati lalu kemudian barulah transaksi ini dilakukan, hal inilah yang membuat para pelaku transaksi tidak pernah memperselisihkan masalah upah ditambah lagi mereka sudah saling memahami satu sama lain akan hal ini.

\section{B. Tinjauan hukum Islam terhadap sistem upah jasa pemelihara hewan ternak (sapi) dengan gabah hasil panen Desa Beroangin}

Sebagaimana yang telah diketahui bersama bahwa dalam hal mengenai permasalahan konsep upah ini bagi para ulama berpendapat boleh atau tidak pelaksanaannya, namun penulis akan meninjau sistem upah pemelihara hewan ternak (sapi) dengan gabah hasil panen yang berlaku

\footnotetext{
${ }^{18}$ Tahir, pemilik sapi (pemberi kerja) Desa Bonra, Kec. Mapilli Kab. Polman, Sulbar, Wawancara oleh penulis di Beroangin, 20 april 2021

${ }^{19}$ Kamaruddin, Tokoh Masyarakat Desa Beroangin, Kec. Mapilli Kab. Polman, Sulbar, Wawancara oleh penulis di Beroangin, 18 April 2021
} 
dikalangan masyarakat Desa Beroangin ditinjau dari hukum Islam dari beberapa sudut pandang yang berlaku pada sistem upah pemelihara hewan ternak (sapi) dengan gabah hasil panen tersebut yaitu :

1. Akad transaksi upah pemelihara hewan ternak (sapi) dengan gabah hasil panen

Dalam istilah fiqih akad secara umum berarti suatu yang menjadi tekad seseorang untuk berusaha dan berbuat, baik yang muncul dari satu pihak, seperti sewa, jual beli, gadai dan wakalah. Akad secara khusus berarti hubungan antara ijab dan qabul dalam lingkup yang ditentukan dan berpengaruh dalam sesuatu. ${ }^{20}$

Dalam akad ijarah perlu memiliki rukun dan syarat sebagai penentunya, yang keduanya harus dipenuhi karena keduanya dapat menentukan apakah akad juga dianggap sah atau tidak. Dalam hal ini sebagian besar Ulama berpendapat bahwa rukun dan syarat ijarah adalah adanya dua orang yang bertransaksi, ijab dan kabul, upah atas jasa yang diberikan oleh pekerja, kesenangan kedua belah pihak dan oleh karena itu objek ijarah adalah beberapa hal yang halal.

Seperti yang telah dituturkan oleh salah seorang tokoh agama yang menyatakan bahwa :

Dalam Islam yang perlu kita perhatikan adalah akadnya, ketika akad transaksi tersebut sudah memenuhi rukun dan syarat, seperti adanya dua orang yang berakad, ijab dan qabul, pekerjaan, upah, kemudian kedua belah pihak yang bertransaksi atas dasar suka sama suka, maka itu dibolehkan namun akan tetapi ketika akadnya bertentangan dengan rukun dan syarat yang sudah saya sebutkan tadi maka jelas transaksi tersebut haram, dan yang paling penting dalam hal ini tidak ada salah satu pihak yang dirugikan. ${ }^{21}$

Dari hasil wawancara di atas dapat dipahami bahwa ketika dalam transaksi muamalah tidak ada salah satu pihak yang dirugikan dan berjalan atas dasar suka sama suka diantara kedua belah pihak maka hukumnya mubah dilalukan, hal ini sejalan dengan firman Allah SWT dalam QS. An-Nisa/ 4:29

${ }^{20}$ Ascarya, Akad dan Produk Bank Syariah, (Jakarta : PT. Raja Grafindo Persada, 2015) h. 35

${ }^{21}$ Pak Rustan, Tokoh Agama Desa Beroangin, Kec. Mapilli Kab. Polman, Sulbar, Wawancara oleh penulis di Beroangin, 26 April 2021 


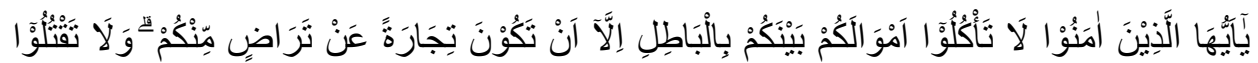

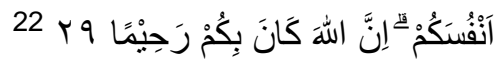

Terjemahnya :

"Wahai orang-orang yang beriman, janganlah kamu saling memakan harta sesamamu dengan jalan yang batil (tidak benar), kecuali dalam perniagaan atas dasar suka sama suka di antara kamu. Janganlah kamu membunuh dirimu. Sesungguhnya Allah adalah Maha Penyayang kepadamu".

Dalam transaksi upah pemelihara hewan ternak (sapi) dengan gabah hasil panen berlangsung atas dasar suka sama suka karena keduanya saling membutuhkan, dalam hal ini pemilik sapi membutuhkan jasa berupa tenaga untuk membantu memelihara sapi-sapi mereka dan disisi lain para buruh (pemelihara hewan ternak sapi) membutuhkan gabah untuk memenuhi kebutuhan hidup mereka, jadi yang ada dalam hal ini adalah unsur tolong menolong. Transaksi ini juga sudah sejak lama dilakukan, dan dalam pelaksanaannya sampai sekarang tidak ada pihak yang merasa dirugikan serta tidak ada pula yang mengklaim bahwa transaksi ini dilaran dalam ajaran Islam.

Merujuk pada beberapa pendapat sebelumnya, jika dilihat dari akad transaksi upah pemelihara hewan ternak sapi dengan gabah hasil panen dikalangan masyarakat Desa Beroangin sudah sesuai dengan rukun dan syarat Ijarah meskipun akad dari transaksi yang berlaku di kalangan masyarakat Desa Beroangin hanya sebatas ucapan lisan tidak tertulis.

2. Upah dengan gabah hasil panen

Dalam Islam jenis upah sudah diatur ketentuannya, sesuatu yang haram tidak boleh dijadikan sebagai objek upah seperti menjanjikan komoditas yang belum jelas adanya, Gabah hasil panen memang pada dasarnya adalah sesuatu yang belum jelas (garar) adanya mengingat karna komoditas ini baru akan ada setelah mengalami proses yang begitu panjang.

\footnotetext{
${ }^{22}$ Departemen Agama RI, Al-Qur'an dan Terjemahnya, (Semarang :PT. Karya
}

Toha Putra, 2002), h.83

${ }^{23}$ Departemen Agama RI, Al-Qur'an Dan Terjemahnya, , h. 153 
Para ulama berselisih pendapat tentang hukum mempekerjakan orang dengan jenis imbalan seperti ini sebahagian mereka ada yang mengizinkan dan sebahagian yang lain melarang.

Adapun dalil mereka yang mengizinkan adalah riwayat Utbah bin Nuddar Bahwa beliau menceritakan, "kami berada di tempat nabi SAW, ketika beliau membaca surah Tha-sin-mim (Al-Qashas) sampai pada kisa musa a.s lalu beliau bersabda ::

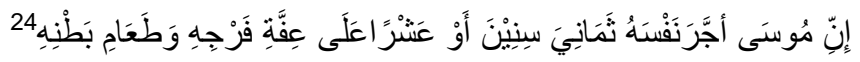

Artinya :

"Sesungguhnya Musa mempekerjakan dirinya selama delapan atau sepuluh tahun dengan imbalan kesucian kemaluannya dan makanan perutnya". ${ }^{25}$

Pendapat diatas adalah pendapat yang dianut oleh Malik dan para ulama Mazhab Hanbali, lebih jauh dijelaskan bahwa Para ualma Mazhab Maliki yang mengizinkan untuk mempekerjakan pekerja dengan upah makanan yang diamakannya dan pakaian yang dipakainya berpandangan bahwa hal itu disesuaikan dengan tradisi yang berlaku. ${ }^{26}$ Hal ini dipertegas oleh kaidah ushul fiqih dimana sesuatu yang sudah menjadi kebiasaan manusia dalam ruang lingkup masyarakat dapat dijadikan landasan hukum selama perbuatan tersebut tidak merugikan salah satu dari pihak yang bekerja sama. ${ }^{27}$

Ulama yang tidak membolehkan seperti asy-Syafi'i Abu Yusuf, Muhammad, para ulama Hadawiah, serta Mansyur Billah menganggapnya tidak boleh disebabkan ketidak jelasan upah. ${ }^{28}$ Dalam hal ini meski transaksi dengan upah gabah hasil panen yang ada di Desa Beroangin tidak jelas adanya namun ketidak jelasannya dipersejelas oleh dua pihak yang bertransaksi dengan cara melakukan kesepakatan diawal akad, apabila sewaktu-waktu terjadi kegagalan panen maka upahnya akan diganti dengan upah jenis yang sama (gabah), bahkan mereka para pemilik sapi (pemberi kerja) menawarkan beberapa pilihan upah dengan jenis yang

${ }^{24}$ Sayyid Sabiq, Fiqih Sunnah, terj. Mujahidin Muhayan jilid 5 (Jakarta : Pena Pundi Aksara, 2011) h. 156

${ }^{25}$ Sayyid Sabiq, Fiqih Sunnah, terj. Mujahidin Muhayan, jilid 5 h. 156

${ }^{26}$ Sayyid Sabiq, Fiqih Sunnah, terj. Mujahidin Muhayan jilid 5 h. 157

${ }^{27}$ Ahmad Djazuli, Kaidah-kaidah Fiqih, (Jakarta : Kencana, 2010), h. 88

${ }^{28}$ Sayyid Sabiq, Fiqih Sunnah, terj. Mujahidin Muhayan jilid 5, h. 156 
lain seperti upah berupa uang dan beras kepada pemelihara sapi (buruh), Sehingga dalam transaksi ini para buruh tidak pernah dirugikan.

\section{PENUTUP}

\section{A. Kesimpulan}

Berdasarkan hasil penelitian kuantitatif yang telah kami lakukan dilapangan, maka kami dapatmengambi lkesimpulan sebagai berikut.

1. Sistem upah pemelihara hewan ternak (sapi) dengan gabah hasil panen yang berlaku dikalangan masyarakat Desa Beroangin. Transaksi ini hanya dilakukan oleh peternak yang tidak hanya berpropesi sebagai peternak namun juga petani penghasil gabah dan buruh yang punya pakan serta lahan yang mendukun untuk hewan ternak (sapi), perhitungan upah buruh dilihat dari banyaknya sapi yang dipelihara kemudian ditentukan satu sapi sama dengan 1 karung gabah seberat $100 \mathrm{~kg}$ dan lama buruh memelihara sapi hingga mendapatkan upah tergantung pada lama proses tumbuh tanaman padi hingga panen, adapun ketika pemilik sapi mengalami kegagalan panen padi maka upah akan diganti dengan upah jenis yang sama dengan cara pemilik sapi akan membeli gabah, atau jenis upah yang lain seperti uang dan beras berdasarkan permintaan buruh.

2. Pandangan hukum Islam terhadap sistem upah pemelihara hewan ternak (sapi) dengan gabah hasil panen yang berlaku dikalangan masyarakat Desa Beroangin yakni rukun dan syarat akad ijarah sudah sesuai, adapun gabah hasil panen yang dijadikan sebagai upah dari pekerjaan ini hukumnya mubah karna ketidak jelasannya diperjelas oleh ganti yang sudah disepakati oleh kedua belah pihak. Selain itu sistem pengupahan ini juga sudah menjadi kebiasaan yang terjadi di masyarakat dan kebiasaan itu bisa menjadi hukum.

\section{B. Saran-Saran}

Kepada pelaku transaksi pemelihara (buruh) dan pemilik sapi (pemberi kerja) agar kiranya melakukan akad secara tertulis tidak hanya dengan lisan saja, agar dapat mengantisipasi perselisihan atau kejadiankejadian yang tidak diinginkan yang sifatnya merugikan.

\section{DAFTAR PUSTAKA}

Al-Qur'an dan Terjemahnya. Semarang:PT. Karya Toha Putra, 2002. 
Azis, Andi Sudarmin. J-Alif Jurnal Penelitian Hukum Ekonomi Syariah, Tinjauan Hukum Islam Terhadap Buruh Pattei Anjoro (Studi Kasus Desa Leko Pa'dis Kecamatan Tinambung Kabupaten Polewali Mandar, Lembaga Penelitian dan Pengabdian Masyarakat Universitas Al Asyariah Mandar, 2017.

Ascarya, Akad dan Produk Bank Syariah, Jakarta : PT. Raja Grafindo Persada, 2015.

Djuwaini, Dimyauddin. Pengantar Fiqh Muamalah. Cet.1; Yokyakarta: Pustaka Belajar, 2008.

Djazuli, Ahmad. Kaidah-kaidah Fiqih, Jakarta : Kencana, 2010.

Idri, Hadis Ekonomi (Ekonomi dalam perspektif Hadis Nabi). Ed. I. Cet. 1; Jakarta: Prenada Media Group, 2015.

Pasaribu, Chairuman dan Suhrawardi K. Lubis, Hukum Perjanjian Dalam Islam. Jakarta: Sinar Grafika, 1996.

Sayyid Sabiq, Fikih Sunnah, Terj. Mujahidin Muhayan, Jilid 5 Jakarta: Pena Pundi Aksara, 2011. 